УДК 82I.I6І.І

ББК $82.3(2 \mathrm{Poc}=\mathrm{Pyc}) 53$
ОБРАЗЫ ЦВЕТОВ В ПОЭТИЧЕСКОМ МИРЕ И. АННЕНСКОГО

(C) 2017 г. Н.В. Налегач

Кемеровский государственный университет, Кемерово, Россия

Дата поступления статьи: 20 февраля 2017 г. Дата публикации: 25 июня 2017 г.

DOI: I0.22455/2500-4247-20I7-2-2-2I2-229

Аннотация: Статья посвящена рассмотрению обобщенного образа цветов/цветка в поэзии И. Анненского в связи с высокой степенью присутствия в его лирике флористической образности. Анализ выявленных 22 стихотворений осуществляется с учетом характерного для поэта ансамблевого принципа представления читателю своих произведений. Опора на историко-литературный подход и методику изучения произведений в аспекте лирической циклизации обуславливает рассмотрение цветочной символики сначала в пределах его поэтических книг «Тихие песни» (I904) и «Кипарисовый ларец» (I9Iо), а затем обращение к текстам, не вошедшим в их состав, с тем, чтобы проверить, какие смыслы оказались магистральными, а какие фоново-периферийными в изучаемом поэтическом мире. В качестве преобладающих источников формирования поэтической семантики цветов у Анненского выступают литературная и народно-поэтическая традиции с опорой на русскую и европейскую культуры, которые в его поэтической системе рассматриваются как единое ментальное пространство. При этом цветочные образы в лирике И. Анненского могут вступать в неожиданные образные параллели (стального колера цветы - мухи, цветы в хрустале - искры из-под молота и т. п.), что способствует организации семантических сдвигов и реализации оригинально-авторского развития поэтических тем. Исследование мотивно-тематических комплексов (любви, красоты, мимолетности, обреченности, гибельной страсти, вдохновения, воспоминания, двоемирия, смерти и воскресения), ставших следствием развития поэтической образности цветка в лирике И. Анненского, позволяет утверждать ключевую роль флористических образов в выражении эстетических взглядов поэта на природу Красоты в разных планах и сферах бытия: земной реальности, искусстве, трансцендентном.

Ключевые слова: цветок, образ, И. Анненский, поэзия, лирика.

Информация об авторе: Наталья Валерьевна Налегач - доктор филологических наук, доцент, ФГБОУ ВО Кемеровский государственный университет, ул. Красная, д. 6, 650000 Кемерово, Россия.

E-mail: nalegach@list.ru 


\section{FLOWER IMAGES IN THE POETIC WORLD OF INNOKENTY ANNENSKY}

This is an open access article

distributed under the Creative

Commons Attribution 4.0

International (CC BY 4.0)
(C) 20I7. N.V. Nalegach

Kemerovo State University,

Kemerovo, Russia

Received: February 20, 2017

Date of publication: June 25, 2017

Abstract: The article examines the image of flowers / flower in the poetry by Innokenty Annensky due to the high relevance of floral imagery in his work. It analyzes 22 poems chosen in accordance with the specific way the poet presented his poems to the reader based on the principle of the "ensemble." Relying on the methodology of literary history and employing the analysis of poetic cyclization, the paper first examines two poetical collections, Quiet Songs (1904) and Cypress Chest (I9IO), and then turns to the poems that were not included in those, in order to distinguish between mainstream and peripheral meanings in his poetical world. The semantics of Annensky's poems draws on literary and popular traditions, both Russian and European, conceived as the solid mental space in his poetical system. At the same time, floral images in his poems often form unusual combinations such as steel color flowers - flies, flowers in the crystal - sparks from the hammer, etc. that show semantic shifts and original interpretation of poetic formulas. The floral imagery contributes to the development of such recurrent themes in Annensky's poetry as love, beauty, doom, passion, inspiration, remembrance, duality, death, and resurrection. The article thus demonstrates the key role of floral images in the expression of the poet's aesthetic view of the nature of Beauty in its different realms and contexts: real life, art, and the transcendent.

Keywords: flower, image, Innokenty Annensky, poetry, lyrics.

Information about the author: Natalya V. Nalegach, DSc in Philology, Associate Professor, Kemerovo State University, Krasnaya 6, 650000 Kemerovo, Russia.

E-mail: nalegach@list.ru 
В небольшом по объему поэтическом наследии И. Анненского обращает на себя внимание большое количество флористических образов. Помимо обобщенного образа цветов/цветка и уже неоднократно привлекавших исследовательское внимание лилий, маков, роз и хризантем [9; г2; г3; I4] в его стихотворениях присутствуют образы лотосов, ирисов, орхидей, тубероз, гиацинтов, азалий, фикусов, резеды, мальвы, левкоев, душистого горошка, тюльпанов, георгин, астр, фиалок, ландышей, жасмина, сирени, чертополоха и одуванчиков. Такое многообразие флористических образов, некоторые из которых неоднократно появляются в его лирике, заставляет задуматься о наличии системы цветочных образов в его поэтическом мире. Можно предположить, что основные мотивно-тематические векторы развития этих образов заданы обобщенным образом цветов/ цветка, поэтому представляется важным обратиться к выявлению и изучению поэтической символики этого образа в стихотворениях И. Анненского. Учитывая тезис Л.Г. Кихней и Н.Н. Ткачевой о «контекстуальном способе символообразования» [7, с. 95] у И. Анненского, можно добавить, что символика обобщенного образа цветка является основой для понимания всего флористического кода в его поэзии. При этом следует учитывать сложившийся в культуре и литературе «язык цветов», результаты изучения которого применительно к русской и европейской традиции XIX-XX вв. представлены в работах М.Р. Ненароковой, А. Ханзен-Лёве, К.И. Шарафадиной [ІІ; I5, с. 599-6І6; І6; І7]. Этот контекст позволяет видеть оригинально-авторское или традиционное поэтическое наполнение флористических образов в отдельной лирической системе. 
В общей сложности в лирике Анненского образ цветка, без упоминания его разновидности, встречается в 22 стихотворениях. В поэтической книге «Тихие песни» это «Который?», «Перед закатом», «Ванька-ключник в тюрьме», «Молот и искры», «Тоска». В «Кипарисовом ларце» - «В марте», «Светлый нимб», «Тоска белого камня», «Дочь Иаира», «Прелюдия», «Буддийская месса в Париже», «Весна», «Тринадцать строк» и «Дети». Остальные - «Из поэмы «Mater Dolorosa»», «На северном берегу», «В ароматном краю», «Тоска кануна», «Поэзия», «Любовь к прошлому», «Нет, мне не жаль цветка» и «Что счастье?» - не были включены автором в свои поэтические книги. Поскольку Анненскому было присуще ансамблевое представление стихотворений, обратимся к раскрытию цветочных образов сначала в пределах его поэтических книг в соответствии с хронологией их выхода к читателю, а затем проверим, какие смысловые линии поддержаны или, напротив, остались за пределами «Тихих песен» (1904) и «Кипарисового ларца» (г9го).

В пяти стихотворениях, вошедших в «Тихие песни», образы цветов связаны с мотивно-тематическими комплексами поэзии, двоемирия, двойничества, гибельной страсти, любви, красоты, тоски, одиночества, обиды и забвения. При этом можно говорить о нескольких источниках формирования поэтической семантики - фольклорном, классическом литературно-поэтическом и широком культурном, преимущественно европейском. Однако в любом случае в творчестве Анненского присутствует оригинально-авторский поворот в развитии традиционной поэтической символики.

В этом смысле, на первый взгляд, наиболее традиционным в обращении к символике цветов выступает стихотворение «Молот и искры», в котором этот образ раскрывается в сочетании мотивов любви, красоты и мимолетности: «Те, скажи мне, завянуть успели ль цветы, / Что уста целовали, любя, / Или, их обогнав, улетели мечты, / Те цветы... Я не знаю: тебя / Я люблю или нет... Не горит ореол / И горит - это ты и не ты» [I, с. 76]. В образе цветов причудливо слито само чувство любви с той, которая их пробудила, что и позволяет поэту объединить этот ряд смыслов в целокупный образ мерцающего переживания любви, когда оба влюбленных сомневаются в своих чувствах и друг в друге, мечтая о гармонии, но обретая лишь муку и страдание в горении страсти, что подчеркнуто неожиданной параллелью цветов и искр, вылетающих из-под кузнечного молота, с которым 
сравнивается жизнь, обрушивающая на лирического героя удар за ударом: «Молот жизни, на плечах мне камни дробя, / Так мучительно груб и тяжел» [I, c. 76]. Эта параллель разрушает традиционно ожидаемый контраст тяготы жизни и красоты, вызывающей любовь, оборачиваясь еще одним ударом по мере развития лирического сюжета: «Молот жизни мучительно, адски тяжел, / И ни искры под ним... красоты... / А ведь, кажется, месяц еще не прошел» [I, c. 76]. Можно видеть, как традиционное семантическое наполнение образа цветов благодаря композиционному решению получает оригинально-авторское развитие, основанное на ироническом опровержении безусловности любви как источника счастья, и высвечивает ее роковую сущность, близкую той, которая характерна для древнегреческой трагедии. В этом смысле примечательно, что в переводе Анненского еврипидовской Федре мучительно тяжело ее покрывало: «Долой покрывало! Мне тяжко, рабыни... (Срывает покрывало и дает рассыпаться темно-золотистым своим и набегающим на щеки волосам) / Пусть волосы льются и плечи оденут...» [6, с. I77], так как страсть к пасынку оказывается непосильной для нее ношей, не содержащей в себе ни искры красоты, перефразируя стихотворение поэта. Не менее примечательно, что в своих комментариях к переводу трагедии Еврипида Анненский связывает мотивы любовной страсти с растительным кодом, утверждая, что «...и Ипполита, и Федру сгубило стремление освободиться от уз пола, от ига растительной формы души» [3, с. 349].

Мотив гибельной страсти, развитию которого способствует в том числе и цветочная образность, более явно воплощен в стилизации народной баллады «Ванька-ключник в тюрьме». При этом образ цветов сочетается как с образом возлюбленной, с которой разлучен ролевой герой баллады, так и с ним самим, сохнущим от любовной тоски и в то же время томящимся в ожидании казни, если вспомнить фольклорный претекст: «Ой, цветики садовые, / Да некому полить! <... А мимо птицей мычется / Злодей - моя тоска... / Такая-то добытчица, / Да не найти крюка?!» [I, с. 7I]. Примечательно, что Анненский высвечивает именно фольклорную характеристику чувства, что гармонирует с выбранным им жанром, и в то же время в контексте всего поэтического сборника возникает удивительное единство древнегреческого и русского народного видения гибельности страсти, поскольку автор, помещая стихотворение в единое смысловое пространство, устанавливает оптическую систему мотивных отражений, в которых самоубийство Федры 
из-за иссушающей ее страсти к Ипполиту как бы преломляется в тоскливой мысли о крюке в сознании Ваньки-ключника. Показательно, что образ цветов устойчиво повторяется в этом мотивно-тематическом комплексе, способствуя сплетению сюжетов о гибельной страсти из разных культурных традиций, актуализированных в полемике с современным Анненскому представлением о мистической спасительной силе любви, восходящем к философско-эстетическому учению В. Соловьева.

С образностью цветов связаны и другие смысловые нюансы в развитии мотива тоски в пределах «Тихих песен». Так, в стихотворении «Тоска» образ «стального колера цветы» вызывает благодаря контексту сложнейшую систему поэтических ассоциаций, подчеркивая и высвечивая метафизическую природу Тоски. Первый план лирического сюжета обусловлен мотивом болезни, приковавшей лирического героя к постели: «Но, лихорадкою томимый, / Когда неделями лежишь, / В однообразьи их томимый / Поймешь ты сладостный гашиш» [I, с. 82]. В этом сюжетном ряду «стального колера цветы» раскрываются как деталь интерьера, скорее всего, рисунок на обоях или обивке мебели. При этом, благодаря смене освещения, цветы из первой строфы соотнесены с центифолиями из последней с помощью ассоциативной поэтики: бледно-розовые овалы первой строфы предсказывают появление разновидности роз посредством сочетания формы и оттенка, в названии которого просвечивает именование цветка. Примечательно, что «стального колера цветы» сочетаются с мотивом обнажившейся сути бытия, утратившего пышные одежды и прикрасы, с которыми как раз ассоциируется особенно пышный сорт роз - центифолии: «Пестрят, назойливы и праздны, / Нагие грани бытия» [г, с. 82]. Их превращение в финале стихотворения в пышные розы как бы возвращает лирического субъекта из состояния болезненного бреда к реальности обычной комнаты.

Интересно отметить, что в состоянии отуманенности сознания образы цветов стального колера смешиваются посредством эпитета «назойливы» и общности колористики с мухами, которые, в свою очередь, тоже из обозначения насекомых развоплощаются до характеристики абстрактных явлений, тем более что в стихотворении «Мухи как мысли» из той же поэтической книги «Тихие песни» этот прием уже был осуществлен с опорой на поэтический опыт Апухтина. Использование винительного падежа во второй строфе: «И мух кочующих соблазны, / Отраву в глянце затая, / 
Пестрят назойливы и праздны, / Нагие грани бытия» [I, с. 82] - затрудняет восприятие синтаксической конструкции, подчеркивая эффект размывания логической стройности и ясности осознанного восприятия мира, выводя на первый план бессознательное смешение черт привычной реальности. Хотя подлежащим являются «мух кочующих соблазны», выступая источником приукрашения «нагих граней бытия», но в самом этом приукрашивании нет смысла, лишь яд, отлучающий лирического героя от истины, подчеркнутый эпитетом, основанным не только на сравнении назойливости мух и соблазнов, но и отсылающим к демоническим мистическим мотивам, обусловленным представлениями о Вельзевуле как владыке мух.

Примечательно, что строфу можно читать не только с начала до конца, но и обратным способом, что позже использовали в своей поэтической практике имажинисты, обосновывая принцип «каталога образов». При обратном чтении финальный образ строфы на синтаксическом уровне начинает играть роль подлежащего, полностью перестраивая смысл. Тем самым «нагие грани бытия», уподобленные однообразному рисунку на обоях комнаты, который складывается из пышных центифолий, но... строгого стального колера, «пестрят назойливы и праздны», отравляя сознание лирического героя, подобно назойливым мухам, неотвязной тоской, оборачивающейся причиной желаний и соблазнов, приковывающих человека к реальности подобно тому, как болезнь приковывает больного к постели. Более того, одурманивающее однообразие нагих граней бытия, одинаково пестрящих единообразными соблазнами, недаром сравнивается то с бредом лихорадящего больного, то с наркотическим опьянением в третьей строфе. Однако прозрение сквозь пестроту навязчивых узоров четких форм закономерно: «стального колера цветы» превращаются в центифолии, а овалы сменяются ромбами в последней строфе, знаменуя выход лирического героя из мира грез. И этот выход обнажает заключенную в нагих гранях бытия суть - Тоску, которая, благодаря приему персонификации, приобретает метафизический характер с невероятно большим спектром значений, располагающихся от синонимии со скукой больного, лишенного возможности действовать, до томления по идеалу, которое присуще романтически настроенному человеку, воплощая отмеченную в работах А.Е. Барзаха «метафизическую подоплеку той тяги, того “томления грани”, которые столь характерны для Анненского» [5, с. 137]. 
Обозначенный контрастный спектр значений семантики тоски разрешается в ироническое сопряжение этих противоположных смыслов, подобно тому как сочетаются в пределах стихотворения образы стального колера цветов и мух кочующих соблазнов. И если образ соблазнов, уподобленных назойливым мухам, строится на развитии мыслей как мух из стихотворения, посвященного памяти Апухтина, то стального колера цветы развивают символ «бреда цветов» из стихотворения «Который?»: «Когда на бессонное ложе / Рассыплются бреда цветы» [І, с. 57]. Это стихотворение встраивается в пределах «Тихих песен» с двумя предыдущими «У гроба» и «Двойник» в несобранный трилистник, объединенный мотивом двойничества. В стихотворении «Который?» этот мотив раскрывается как высвобождение творческого вдохновенного «я», заключенного в лирическом герое, скованном условностями так называемого «дневного» обыденного существования и в духе тютчевской традиции обретающего полноту бытия в ночные часы, позволяющие откинуть «докучную маску». Тем не менее заданный романтический мотив двойничества у Анненского развивается в споре с предшественниками благодаря системе авторских оценок, пронизывающих образный ряд стихотворения и мотив двоемирия. Первым оценочно окрашенным символом в этом ряду оказываются «бреда цветы». Согласимся с наблюдением В.В. Мусатова, что «метафора “бреда цветы” содержит мучительно двойной смысл, в ней, как в клеточке органического целого, содержится структурный отпечаток общего - творческой позиции Анненского. Цветы у Анненского - чаще всего символ непрочной и хрупкой красоты <...>. В контексте этого стихотворения цветы, рассыпающиеся “на бессонном ложе”, - красота торжествующей мечты, освобожденной от “уз бытия”. Это - отвага и победа воображения <...>. Но мечта не случайно названа здесь бредом. Логика воображения насколько же оспаривает законы реальности, насколько реальность оттеняет его иллюзорный смысл» [Іо, с. І6].

Показательно, что в стихотворении тоже присутствует образ рассветного розового тумана, обнажающего призрачную суть соблазна романтического двойничества. Прорыв к истине, который, как казалось лирическому герою, состоялся в его ночном вдохновенном состоянии, оказывается не менее иллюзорным, чем «докучная маска» будничного существования, откинутая ради достижения мира идеалов: «На сердце ее 
я, бледнея, / За розовой раной слежу, // За розовой раной тумана, / И пьяный от призраков взор / Читает там дерзость обмана / И сдавшейся мысли позор» [I, с. 57]. В свете этого обнажается ироническое сопряжение двух оторванных друг от друга путей воплощения «я» в реальности: масочность дня и цветистая бедовость ночи как житейски регламентированное и творчески свободное состояние человека сходятся в финальном вопросе, обращенном к Творцу: «О царь Недоступного Света, / Отец моего бытия, / Открой же хоть сердцу поэта, / Которое создал ты я» [I, c. 57]. Завершающий стихотворение мотив недоумения в соседстве со смыслом стихотворения «Двойник» ставит под сомнение традиционную романтическую оценку двоемирия и двойничества, высвечивая иллюзорную сущность обоих миров в состоянии их разрыва.

Возвращаясь к образности садовых цветов, отметим, что появляются они не только в балладе «Ванька-ключник в тюрьме», но и в стихотворении «Перед закатом»: «Все глазами взять хочу я из темнеющего сада... // Щетку желтую газона, / На гряде цветок забытый» [г, с. 65]. Форма единственного числа, в котором употреблено существительное «цветок», усиливает мотивы одиночества и заброшенности. Образ забытого одинокого цветка метонимически сочетается с образом разоренного, даже вырубленного сада: «Топора обиды злые, / Все, чего уже не стало» [I, с. 65], в то же время храня и воплощая самим фактом своего существования былое великолепие теперь исчезнувшего мира. Отсюда и сплетение мотивов воспоминания, узнавания, мечты и поэзии, которыми окружены образы погубленного сада. Так, стихотворение начинается стихами: «Гаснет небо голубое, / На губах застыло слово» [I, с. 64], ассоциативно намекающими на состояние замирающего вдохновения, и завершается мотивом надежды на оживление и силу этого состояния: «Чтобы сердце, сны былые / Узнавая, трепетало...» [I, с. 65]. Узловым образом, связавшим мотивы прекрасного прошлого, обидного настоящего, воспоминания, дарующего надежду и становящегося источником вдохновения, становится забытый одинокий садовый живой цветок, композиционно сочетающийся с самоощущением лирического «я».

Подводя итоги развитию символики обобщенного образа цветов в «Тихих песнях», отметим ее полемическую заостренность по отношению к традиционной семантике, что достигается посредством семантических сдвигов, когда привычное значение иронически смещается или даже опро- 
вергается благодаря контексту или неожиданным образным параллелям, как в случае сочетания образности цветов и мух. Следует отметить, что такой ироничный, по сути, фокус восприятия цветочной символики характерен и для стихотворений, вошедших в «Кипарисовый ларец».

При этом в стихотворениях второй поэтической книги присутствует и совершенно традиционное обращение к поэтической символике цветов. Как правило, это наблюдается тогда, когда образ выступает не центральным, а фоново-вспомогательным. Например, в стихотворении «В марте» образ садовых весенних цветов вписывается в пейзаж, поддерживающий развитие темы любви: «Позабудь соловья на душистых цветах, / Только утро любви не забудь!» [г, с. 88], а в стихотворении «Дети» образы цветов практически сведены к аллегорическому обозначению радости и счастья: «Нам - острог, но им - цветов... / Солнца, люди, нашим детям!» [I, c. I57]. Тем не менее в остальных стихотворениях символика цветов, как и в «Тихих песнях», основана на авторской игре с традиционными значениями. Так, мотив мимолетности цветочной красоты в поэзии Анненского соединяется с памятью об их употреблении в похоронной обрядности, что приводит к устойчивому их упоминанию в развитии темы смерти, как, например, в стихотворениях «Светлый нимб», «Тоска белого камня» и «Дочь Иаира». В каждом из них можно видеть разную нюансировку темы смерти посредством цветочной образности.

Самый простой вариант - образ двух цепей букетов в стихотворении «Тоска белого камня», где они ассоциируются с цветами, возлагаемыми на могильные плиты: «На две цепи букетов / Возле плит белоснежных» [г, с. I08]. В двух других упомянутых стихотворениях ассоциативные ряды сложнее. В сонете «Светлый нимб» такие образные детали, как свечи, куренье, моленья и слезы, черная фата, вызывают ассоциации с отпеванием, одним из атрибутов которого становятся и бледнеющие, сжимающиеся цветы. Этот образ способствует развитию уместного в контексте данной тематики мотива увядания, в противовес которому в душе лирического героя пробуждается чувство любви.

В стихотворении «Дочь Иаира» цветочная образность соотнесена со снежным покровом посредством сходства форм цветов и снежинок, как если бы они были в виде узора нанесены на ткань: «Для чего с контуров нежной, / Непорочной красоты / Грубо сорван саван снежный, / Жечь за- 
чем ее цветы?» [I, с. II5]. Образ сжигаемых весенним солнцем снежных цветов соотносится с ключевым настроением стихотворения: «Только мне в пасхальном гимне / Смерти слышится призыв» [I, с. II5]. Думается, суть этого настроения не в полемике с христианской традицией, не в споре с чудом воскресения, удвоенным в финале чудом воскрешения дочери Иаира, а, скорее, в близком архаичному переживании круга бытия, в котором рождение и смерть - неразрывно связанные, как бы оборачивающиеся друг другом явления, при котором рождение одного явления происходит из смерти другого, как в случае со сменой времен года: для рождения весны необходима гибель зимы. Это закрепленное в обрядовой фольклорной традиции представление посредством, например, сожжения чучел окрашивает и восприятие лирическим героем весны. При этом соотнесенная с весной и новой жизнью дочь Иаира не менее дорога сердцу лирического «я», чем сжигаемые весенним солнцем снежные цветы, из которых «соткан» снежный покров, укрывающий землю, в то же время уподобленный покрывалу, которым накрыто тело девушки, спящей мертвым сном, перед тем, как ее воскресил голос Спасителя: «Не мигнул фитиль горящий, / Не зазыбил ветер ткань... / Подошел Спаситель к спящей, / И сказал ей тихо: “Встань”» [г, с. гі6]. В этой параллели привлекает внимание тихая бережная поступь Христа, противопоставленная яростному сжигающему весеннему солнцу. Чудо воскрешения открывается здесь и в том, что прежнее состояние не уничтожается, а становится частью обновленной и воскрешенной жизни. Таким образом, в пределах стихотворения благодаря в том числе и образу сжигаемых снежных цветов-снежинок противопоставлены два мировидения - языческое и христианское - как природное и культурное. Недаром воздействие первого дано через природные образы сжигающих солнечных лучей, а второго - выражены посредством Слова. Но в то же время благодаря сопряжению мотивов смерти и воскресения («Только мне в пасхальном гимне / Смерти слышится призыв») они не только противопоставлены, но и сопоставлены в восприятии лирического «я», подчеркивая глубинную неразрывную слитность этих планов бытия.

Цветы как элемент таинственного обрядового действа, остающегося непонятым окружающими, представлены и в стихотворении «Буддийская месса в Париже»: «Обедня кончилась, и сразу ожил зал, / Монгол с улыбкою цветы нам раздавал, / И, экзотичные вдыхая ароматы, / Спешили к 
выходу певцы, и дипломаты, / И дамы <...> // И странно было мне, и жутко увидать, / Как над улыбками спускалися вуали / И пальцы нежные цветы богов роняли» [I, с. I27-I28]. Подобно тому, как в стихотворении «Дочь Иаира» лирический герой остро переживает гибель цветов как гибель красоты, в этом стихотворении можно видеть тот же мотив, усиленный мотивом небрежения к божественной тайне, которой дышат изображенные здесь экзотические цветы.

Помимо образов растущих, цветущих, сорванных, сжигаемых, бросаемых цветов в поэзии Анненского присутствует образ цветов, бережно поставленных в вазу, «цветов в хрустале». Этот образ встречается в пределах «Кипарисового ларца» в стихотворениях «Прелюдия» и «Тринадцать строк». Изысканная красота цветов в хрустале в поэзии Анненского становится одним из наиболее точно выраженных образов, передающих его видение судьбы прекрасного в этом мире. Так, М. Крепс, анализируя сочетание образов цветов в хрустале и красоты, отмечал: “Ты” здесь конечно же не женщина, а Неземная Краса Анненского, отражающаяся в цветах и игре света в хрустале. Вообще хрусталь, цветы и драгоценные камни - слабость Анненского, его истинная привязанность. Игра света в камнях, его искры и переливы укрепляют веру поэта в величие Божественного замысла» [8, c. 87]. С последним оптимистичным утверждением можно не согласиться, так как в отличие от большинства своих современников, очарованных размышлениями В. Соловьева о спасительных смыслах Любви и Красоты, И. Анненский, сохраняя логику «вещного мира», подчеркивает мимолетность и обреченность красоты. Однако его авторская воля направлена не на утверждение бессмыслицы, становящейся следствием этой обреченности, а, напротив, именно смертность делает проявления красоты подлинно ценными, позволяя остро и уникально пережить пронзительную силу Прекрасного. Это одна из излюбленных мыслей Анненского, окрашивающая его эстетические установки и проявляющаяся во всем его творчестве. Так, именно смертность позволяет Иксиону в его трагедии «Царь Иксион» любить прекрасную богиню с такой силой, что недоступна бессмертным богам, утвердительно отвечая на вопрос потрясенной его дерзостью Геры: «Или сильней, чем боги, люди любят?» [г, с. 384].

Возвращаясь к символике цветов в хрустале, закономерно связанных с темой любви и красоты в усеченном сонете «Тринадцать строк»: 
«Я люблю только ночь и цветы / В хрустале, где дробятся огни, / Потому что утехой мечты / В хрустале умирают они... / Потому что - цветы это ты» [I, c. I49] - и с темой искусства и любви к жизни в «Прелюдии»: «Я жизни не боюсь. Своим бодрящим шумом / Она дает гореть, дает светиться думам. / Тревога, а не мысль растет в безлюдной мгле, / И холодно цветам ночами в хрустале. / Но в праздности моей рассеяны мгновенья...» [I, с. І26], - отметим их важность для понимания эстетических установок Анненского, обусловленных его особым пониманием смертности как условия сохранения человечности, феноменологически осмысленной в ценностной системе гуманизма, от которой Анненский не отказывается и полемически продолжает ее утверждать вопреки распространившимся в русском символизме эстетическим установкам Ф. Ницше. Смертность не просто выступает как отличительное свойство человека. Именно она побуждает подлинно искать и жаждать высоких идеалов, в то время как бессмертие оборачивается их утратой в силу непонимания страдания и, как следствие, неспособности к состраданию, что особенно отчетливо выражено в его драматургии в образах богов, которые наделены устойчиво повторяющимся древнегреческим мотивом смеха. В этом смысле цветы в хрустале - красота, оберегаемая и искусно умноженная и в то же время обреченная смерти, - наиболее точно передают эту мысль Анненского в лирике.

Наконец, следует обратить внимание на образ искусственных цветов, которые в «Тихих песнях» встречались в стихотворении «Тоска», а в «Кипарисовом ларце» - в стихотворении «Весна» из микроцикла «Контрафакции». Если естественные цветы в творчестве Анненского соотносятся с путями и судьбами идеала в земном измерении, то искусственные цветы чаще связаны с мотивами подверженности соблазнам всего того, что приукрашивает собой «нагие грани бытия». Так в стихотворении «Весна» представлен образ шляпки, украшенной цветами и самой превращающейся в цветок на березе, в силу контраста и особенностей развития мотива страсти, которой отдаются молодые люди и которая в следующем стихотворении становится причиной гибели (мотив самоубийства ассоциативно выражен в стихотворении «Осень» в образе созревшего из того цветка мучительно-черного стручка, повисшего на той же березе).

В стихотворениях, не вошедших в поэтические книги Анненского, символика цветов раскрывается сходным образом, вписываясь в созданную 
им лирическую систему. Так, в самостоятельном отрывке «Из поэмы “Mater Dolorosa” » образ цветов возникает в восприятии лирическим героем звуков отдаленной шарманки, отсылая к мотивно-тематическому комплексу искусства и путей идеала в земной реальности: «Как я любил от городского шума / Укрыться в сад, и шелесту берез / Внимать, в запущенной аллее сидя... / Да жалкую шарманки отдаленной / Мелодию ловить. Ее дрожащий / Сродни закату голос: о цветах / Он говорит увядших и обманах» [I, c. I6I]. К этой же группе примыкают образы беспокойных цветов из сонета «Поэзия» («Творящий дух и жизни случай...») и цветка в хрустале из «Нет, мне не жаль цветка, когда его сорвали...», продолжающего образ цветов в хрустале. С мотивно-тематическим комплексом мимолетности красоты и ее обреченности связан также образ цветов в стихотворениях «На северном берегу», «Что счастье?» и «Любовь к прошлому».

Можно видеть, что Анненский создает стройную систему в употреблении цветочных образов, в основании которой оказывается утверждение ценности мимолетности живой красоты, ее обреченности природному процессу умирания в противовес мнимым ценностям «вечной» жизни искусственных цветов, оборачивающихся иллюзорной подменой смысла жизни соблазнами суетного существования, как, например, в стихотворении «Там», где «белел Эрот бескрылый / Меж искусственных азалий», которые тем не менее не дают пережить ни подлинной радости, ни приобщения к идеалу, а только опьяняют сознание до того предела, когда человек оказывается на пороге выхода из «Трактира жизни». В этом смысле примечательно авторское противопоставление в пределах поэтического мира искусственного искусному в образах искусственных цветов и цветов в хрустале, при котором искусство оказывается формой обретения подлинной жизни, так как не подменяет ее искусственными ценностями в попытке подражать природным формам, а лишь искусно подчеркивает ценность самой жизни, как в случае с усилением красоты цветов, поставленных в хрустальную вазу. 


\section{Список литературы}

I Анненский И.Ф. Стихотворения и трагедии / вступ. ст., сост., подгот. текста, примеч. А.В. Федорова. Л.: Сов. писатель, г990. 640 с. Анненский И.Ф. Из наблюдений над языком и поэзией Русского Севера. СПб.: Тип. имп. акад. наук., г883. І6 с. Анненский И.Ф. Трагедия Ипполита и Федры // Анненский И.Ф. Театр Еврипида: в 3 т. СПб.: Тип. Книгоиздательского т-ва «Просвещение», I906. Т. І. С. 329-349. Барзах А.Е. «Тоска» Анненского // Гумилевские чтения. СПб.: Изд-во С.-Петерб. гуманитар. ун-та профсоюзов, І996. С. 32-43. Барзах А. Обратный перевод. СПб.: Митин журнал, І999. 420 с.

6 Eврипид. Ипполит // Еврипид. Трагедии: в 2 т. / пер. с древнегреч. Иннокентия Анненского / изд. подгот. М.Л. Гаспаров, В.Н. Ярхо. М.: Ладомир; Наука, г999. Т. І. С. 168-230. Кихней Л.Г., Ткачева Н.Н. Иннокентий Анненский. Вещество существования и образ переживания. М.: Диалог-МГУ, г999. г23 с. Крепс M. Анализ стихотворения Иннокентия Анненского «Моя тоска» // Новый журнал. І98г. Кн. І44. С. 68-94. Леонова Н.Е. Образ лилии в искусстве модерна и в поэзии И.Ф. Анненского // Вестник Новгородского госуниверситета. Сер. «Филология». Специальный выпуск: «Мусатовские чтения - 2009». 2010. № 56. С. 40-43. Мусатов В.В. «Тихие песни» Иннокентия Анненского // Известия РАН. Сер. Лит. и яз. г992. Т. 5г. № 6. С. I4-24.

Ненарокова М.Р. Язык цветов: между литературой и ботаникой // Проблемы национальной литературы. Художественные поиски второй половины XX в. и современность. Материалы Всероссийской научной конференции, посвященной гоо-летию со дня рождения писателя, учителя, фольклориста Р.А. Кулаковского (г. Якутск, I8-І9 июня 2014 г.) / отв. ред. Л.Р. Кулаковская. Новосибирск, 20I5. C. IO6-II4.

Петрова Г.В. Фетовские «Параллели» Иннокентия Анненского // Вестник Новгородского госуниверситета. Сер. «Филология». Специальный выпуск: «Мусатовские чтения - 2009». 2010. № 56. С. 53-57.

I3 Полякова Н. Сравнительная характеристика вариантов стихотворения И.Ф. Анненского «Маки» // Иннокентий Федорович Анненский (г855-I909). Материалы и исследования: По итогам международных научно-литературных чтений, посвященных І5о-летию со дня рождения И.Ф. Анненского / Редакторы-составители С.Р. Федякин, С.В. Кочерина. М.: Издательство Литературного института им. А.М. Горького, 2009. С. I53-І6о.

I4 Рубинчик О. «Там были розы...»: тема розы у Иннокентия Анненского // Некалендарный XX век. М.: Азбуковник, 20II. С. І27-139. 
I5 Ханзен-Лёве А. Русский символизм. Система поэтических мотивов. Мифопоэтический символизм. Космическая символика / пер. с нем. М.Ю. Некрасова.

СПб.: Академический проект, 2003. С. 599-616.

I6 Шарафадина К.И. «Алфавит Флоры» в образном языке литературы пушкинской эпохи (источники, семантика, формы). СПб.: Петербург. ин-т печати, 2003. 309 с.

I7 Шарафадина К.И. «Язык цветов» в русской поэзии и литературном обиходе первой половины XIX века: автореф. дис. ... д-ра филол. наук. СПб., 2004. 48 с. 


\section{References}

I Annenskij I.F. Stihotvorenija i tragedii [Poems and tragedy]. Intro., comp., ed. and comment. by A.V. Fedorov. Leningrad, Sovetskij pisatel’ Publ., I990. 640 p. (In Russ.) Annenskij I.F. Iz nabljudenij nad jazykom i pojeziej Russkogo Severa [The study of language and poetry of the Russian North]. St. Petersburg, tip. imp. akad. nauk. Publ., I883. I6 p. (In Russ.)

3 Annenskij I.F. Tragedija Ippolita i Fedry [The tragedy of Hippolytus and Phaedra]. Annenskij I.F. Teatr Evripida: $v 3$ t. [The theatre of Evripides: in 3 vol.]. St. Petersburg, tip. Knigoizdatel'skogo t-va "Prosveshchenie" Publ., I906, vol. I, pp. 329-349. (In Russ.)

4 Barzah A.E. “Toska” Annenskogo ["Sorrow” by Annensky]. Gumilevskie chtenija [Gumilev Conference]. St. Petersburg, Izd-vo S.-Peterb. gumanitar. un-ta profsojuzov Publ., I996, pp. 32-43. (In Russ.)

Barzah A. Obratnyj perevod [Retranslation]. St. Petersburg, Mitin zhurnal Publ., I999. 420 p. (In Russ.)

Evripid. Ippolit [Hippolyte]. Evripid. Tragedii: $v 2 t$., trans. from Ancient Greek by Innokenty Annensky, ed. M.L. Gasparov, V.N. Jarho. Moscow, Ladomir; Nauka Publ., I999, vol. I, pp. I68-230. (In Russ.)

7 Kihnej L.G., Tkacheva N.N. Innokentij Annenskij. Veshhestvo sushhestvovanija i obraz perezhivanija [Innokenty Annensky. The substance of existence and image of emotional experience]. Moscow, Dialog-MGU Publ., I999. I23 p. (In Russ.)

Kreps M. Analiz stihotvorenija Innokentija Annenskogo "Moja toska” [The analysis of the poem "My Sorrow" by Annensky]. Novyj zhurnal, I98I, book I44, pp. 68-94. (In Russ.)

Leonova N.E. Obraz lilii v iskusstve moderna i v pojezii I.F. Annenskogo [The image of the lily in Art Nouveau and Annensky's poetry]. Vestnik Novgorodskogo gos. universiteta, Series Philology, special issue of the conference: "Musatovskie chtenija - 2009", 20Io, no 56, pp. 40-43. (In Russ.)

Musatov V.V. “Tihie pesni” Innokentija Annenskogo [Quiet Songs by Innokenty Annensky]. Izvestia RAN, Series Literature and Language, I992, vol. 5I, no 6, pp. I4-24. (In Russ.)

II Nenarokova M.R. Jazyk cvetov: mezhdu literaturoj i botanikoj [The Language of Flowers: between literature and botany]. Problemy nacional'noj literatury. Hudozhestvennye poiski vtoroj poloviny XX v. i sovremennost'. Materialy Vserossijskoj nauchnoj konferencii, posvjashchennoj Ioo-letiju so dnja rozhdenija pisatelja, uchitelja, fol'klorista R.A. Kulakovskogo (g. Jakutsk, I8-I9 ijunja 20I4 g.) [The Problems of national literature. Artistic quests of the second half of the $20^{\text {th }}$ century. Proceedings of the bicentennial conference in memory of R.A. Kulakovsky, writer, teacher, and anthropologist], ed. L.R. Kulakovskaya. Novosibirsk, 20I5, pp. IO6-II4. (In Russ.) 
Petrova G.V. Fetovskie “Paralleli” Innokentija Annenskogo ["Parallels” between Afanasy Fet and Innokenty Annensky].Vestnik Novgorodskogo gos. universiteta, Philology series, special issue of the conference "Musatovskie chtenija - 2009", 20I0, no 56, pp. 53-57.(In Russ.)

I3 Poljakova N. Sravnitel'naja harakteristika variantov stihotvorenija I.F. Annenskogo "Maki" [Comparative characteristics of the variants of Annensky's poem "Poppies"]. Innokentij Fedorovich Annenskij (I855-1909). Materialy i issledovanija: Po itogam mezhdunarodnyh nauchno-literaturnyh chtenij, posvjashchennyh I5o-letiju so dnja rozhdenija I.F. Annenskogo [Innokenty Fedorovitch Annensky (I855-I909).

Proceedings and studies. On the results of the international conference dedicated to Annensky's I5o year anniversary], eds. S.R. Fedjakin, S.V. Kocherina. Moscow, Izdatel'stvo Literaturnogo instituta im. A.M. Gor'kogo Publ., 2009, pp. I53-I60. (In Russ.)

I4 Rubinchik O. “Tam byli rozy...”: tema rozy u Innokentija Annenskogo [“There were the roses...”. The theme of the rose in Annensky]. Nekalendarnyj XX vek [Long Twentieth century]. Moscow, Azbukovnik Publ., 20II, pp. I27-I39. (In Russ.)

I5 Hanzen-Ljove A. Russkij simvolizm. Sistema pojeticheskih motivov. Mifopojeticheskij simvolizm. Kosmicheskaja simvolika [Russian symbolism. System of poetic motifs. Mythopoetic symbolism. Symbolism of Space], trans. from German. M.U. Nekrasova. St. Petersburg, Akademicheskij proekt Publ., 2003, pp. 599-6I6. (In Russ.)

I6 Sharafadina K.I. "Alfavit Flory” v obraznom jazyke literatury pushkinskoj epohi (istochniki, semantika,formy) ["The Alphabet of Flora" in the figurative language of literature of Pushkin's time (sources, semantics, forms)]. St. Petersburg, Peterburg. in-t pechati Publ., 2003. 309 p. (In Russ.)

I7 Sharafadina K.I. “Jazyk cvetov" v russkoj pojezii i literaturnom obihode pervoj poloviny $X I X v e k a$ ["The Language of Flowers" in the Russian poetry and literary everyday life of the first half of the $19^{\text {th }}$ century]. PhD diss. (Synopsis). St. Petersburg, 2004. 48 p. (In Russ.) 